\title{
Effect of photodynamic therapy on clinical isolates of Staphylococcus spp
}

\section{Michelle Miyabe(a) \\ Juliana Campos Junqueira(a) Anna Carolina Borges Pereira da Costa $(a)$ \\ Antonio Olavo Cardoso Jorge ${ }^{(a)}$ Martha Simões Ribeiro ${ }^{(b)}$ \\ Ilíria Salomão Feist ${ }^{(b)}$}

(a) Department of Biosciences and Oral Diagnosis, School of Dentistry of São José dos Campos, UNESP - Univ. Estadual Paulista, São José dos Campos, SP, Brazil.

(b) Center for Lasers and Applications, Institute of Energetic and Nuclear Researches IPEN-CNEN/SP, Universidade de São Paulo - USP, São Paulo, SP, Brazil.

\section{Corresponding author:}

Anna Carolina Borges Pereira da Costa Universidade Estadual Paulista (UNESP) Av. Engenheiro Francisco José Longo, 777, São Dimas

São José dos Campos - SP - Brazil CEP: 12245-000

E-mail:carolbiolog@yahoo.com.br

Received for publication on Oct 09, 2010 Accepted for publication on Nov 17, 2010
Abstract: Staphylococcus spp. are opportunistic microorganisms known for their capacity to develop resistance against antimicrobial agents. The objective of this study was to evaluate the effect of photodynamic therapy (PDT) on 20 Staphylococcus strains isolated from the human oral cavity, including S. aureus, S. schleiferi, S. epidermidis, S. capitis, S. haemolyticus, and S. lentus. A suspension of each Staphylococcus strain $\left(10^{6}\right.$ cells/ $\mathrm{mL}$ ) was submitted to PDT using methylene blue and a low power laser. The isolated effects of methylene blue, laser treatment and ciprofloxacin were also evaluated. After the experimental treatments, $0.1 \mathrm{~mL}$ aliquots of the suspensions were seeded onto BHI agar for determination of the number of colony-forming units $(\mathrm{CFU} / \mathrm{mL})$. The results were analyzed by analysis of variance and Tukey's test $(p \leq 0.05)$. The mean reduction in bacterial counts of the strains submitted to PDT ranged from 4.89 to $6.83 \mathrm{CFU}$ $\left(\log _{10}\right) / \mathrm{mL}$, with the observation of a decreasing susceptibility to treatment of S. schleiferi, S. haemolyticus, S. epidermidis, S. capitis, S. aureus, and $S$. lentus. The results showed that PDT was effective in reducing the number of viable cells of all clinical Staphylococcus isolates studied.

Descriptors: Staphylococcus; Photochemotherapy; Methylene Blue; Ciprofloxacin.

\section{Introduction}

Several species of the genus Staphylococcus can be isolated from the human oral cavity and are part of the transient microbiota. ${ }^{1}$ These microorganisms are found in the oral cavity of approximately $95 \%$ of healthy individuals and have become a matter of concern because of their capacity to develop resistance against antimicrobial agents. ${ }^{2,3}$ In addition to their involvement in oral diseases, such as angular cheilitis, parotiditis, staphylococcal mucositis and periodontitis, these bacteria are the causative agents of severe skin and soft tissue infections that are associated with an increased risk of complications, such as bacteremia, pneumonia and endocarditis. ${ }^{1,4-7}$

Methicillin-resistant Staphylococcus aureus (MRSA) has been isolated from the oral cavity of healthy individuals, a finding that indicates an increased risk of dissemination to other sites. ${ }^{7,8}$ Other Staphylococcus species have also been recognized as important etiological agents of opportunistic infections in individuals with differing predisposing factors, and some isolates have shown a reduced susceptibility to $\beta$-lactam antibiotics. ${ }^{3,9}$ Vancomycin is the antibiotic of choice in the case of reduced 
$\beta$-lactam susceptibility. However, although resistance is rare, therapeutic failure is increasingly being reported. ${ }^{4}$

Photodynamic therapy (PDT) has emerged as a therapeutic option for the treatment of infectious diseases. This therapy consists of the activation of a photosensitive dye with light of an appropriate wavelength, consequently resulting in the production of reactive oxygen species, such as free radicals and singlet oxygen. These reactive oxygen species can damage DNA and the cell membrane, resulting in the leakage of cell components, inactivation of transport systems and cell death. ${ }^{10,11}$

The objective of the present study was to evaluate the effect of photodynamic antimicrobial chemotherapy on different Staphylococcus strains isolated from the human oral cavity.

\section{Materials and Methods Staphylococcus strains}

The study was approved by the Ethics Committee of the School of Dentistry of São José dos Campos, UNESP (07/2007-PH/CEP).

Twenty Staphylococcus strains isolated from the human oral cavity ( $S$. aureus, $\mathrm{n}=5 ; \mathrm{S}$. schleiferi, $\mathrm{n}=5 ;$ S. epidermidis, $\mathrm{n}=6 ;$ S. capitis, $\mathrm{n}=2 ;$ S. haemolyticus, $\mathrm{n}=1$, and $S$. lentus, $\mathrm{n}=1$ ) were studied. These strains were obtained from the Laboratory of Microbiology and Immunology, School of Dentistry of São José dos Campos, UNESP.

Twenty-four-hour cultures, incubated at $37^{\circ} \mathrm{C}$ on mannitol agar (Difco, Detroit, MI, USA), were inoculated into brain-heart infusion broth (Difco) and incubated for a further $18 \mathrm{~h}$ at $37^{\circ} \mathrm{C}$. The cultures were then centrifuged at $1300 \mathrm{x} g$ for $10 \mathrm{~min}$, the supernatant was discarded, and the cell pellet was resuspended in $5 \mathrm{~mL}$ sterile saline $(0.85 \% \mathrm{NaCl})$. This procedure was repeated once. The suspension was standardized in a spectrophotometer (B582, Micronal, São Paulo, Brazil) to an optical density of 0.374 at a wavelength of $490 \mathrm{~nm}$, corresponding to $10^{6}$ cells $/ \mathrm{mL}$.

\section{Photosensitizer, laser and antibiotic treatment}

Methylene blue (MB), at a concentration of
$3 \mathrm{mM}$, was used for photosensitization of the Staphylococcus strains. The dye solution was prepared by dissolving the powder (Sigma-Aldrich, Steinheim, Germany) in $0.85 \% \mathrm{NaCl}$ and filtering it through a $0.22-\mu \mathrm{m}$ membrane filter (Millipore, São Paulo, Brazil). After filtration, the dye solution was stored in the dark.

A gallium-aluminum-arsenide laser (Easy Laser, Clean Line, Taubaté, Brazil), emitting light at $660 \mathrm{~nm}$ (visible red), was used as the light source. The wavelength of the laser corresponds to the maximum absorption of MB. The laser settings were as follows: power of $35 \mathrm{~mW}$, energy of $10 \mathrm{~J}$, time of $285 \mathrm{~s}$, fluence rate of $92 \mathrm{~mW} / \mathrm{cm}^{2}$, and fluence of $26.3 \mathrm{~J} / \mathrm{cm}^{2}$.

Ciprofloxacin (Vivência Compounding Pharmacy, Pindamonhangaba, SP, Brazil) was used as an antibiotic at a concentration of $1.6 \mathrm{mg} / \mathrm{mL}$.

\section{In vitro photosensitization}

Thirty assays were carried out for each suspension for a total of 600 assays. The Staphylococcus spp. strains were submitted to the following experimental conditions $(n=6)$ :

a. photosensitization with $\mathrm{MB}$ and laser irradiation $(\mathrm{P}+\mathrm{L}+)$;

b. photosensitization with $\mathrm{MB}$ in the absence of light $(\mathrm{P}+\mathrm{L}-)$;

c. treatment with saline and laser irradiation $(\mathrm{P}-$ $\mathrm{L}+)$;

d. treatment with the antibiotic $(A B)$; and

e. treatment with saline in the absence of light as a control group $(\mathrm{P}-\mathrm{L}-)$.

Sterile 96-well flat-bottom microtiter plates with a lid (Costar Corning, New York, USA) were used. An aliquot $(0.1 \mathrm{~mL})$ of the bacterial suspension was added to each well (area of $0.38 \mathrm{~cm}^{2}$ ). Next, $0.1 \mathrm{~mL}$ of the photosensitizer was added for groups $\mathrm{P}+\mathrm{L}+$ and $\mathrm{P}+\mathrm{L}-, 0.1 \mathrm{~mL}$ of saline for groups $\mathrm{P}-\mathrm{L}+$ and $\mathrm{P}-\mathrm{L}-$, and $0.1 \mathrm{~mL}$ of the antibiotic for group $\mathrm{AB}$. The plates were then shaken for $5 \mathrm{~min}$ in an orbital shaker (Solab, Piracicaba, Brazil). After this period, the contents of the wells of groups $\mathrm{P}+\mathrm{L}+$ and $\mathrm{P}-\mathrm{L}+$ was irradiated as described above. The samples were irradiated under aseptic conditions in a laminar flow chamber in the dark. 
After the experimental treatments, serial dilutions were prepared and $0.1-\mathrm{mL}$ aliquots of the dilutions were seeded in duplicate onto brain-heart infusion agar plates (Difco). After incubation for $24 \mathrm{~h}$ at $37^{\circ} \mathrm{C}$, the number of colony-forming units (CFU/ $\mathrm{mL}$ ) was determined, and the results were log-transformed $\left(\log _{10}\right)$.

\section{Statistical analysis}

The results $\left(\log _{10} \mathrm{CFU} / \mathrm{mL}\right)$ were analyzed by analysis of variance (ANOVA) and the Tukey test, with the level of significance set at $5 \%$, using the Minitab 14.0 program.

\section{Results}

Figures 1 and 2 show the mean and standard deviation of CFU/mL obtained for the different Staphylococcus species studied under each experi-

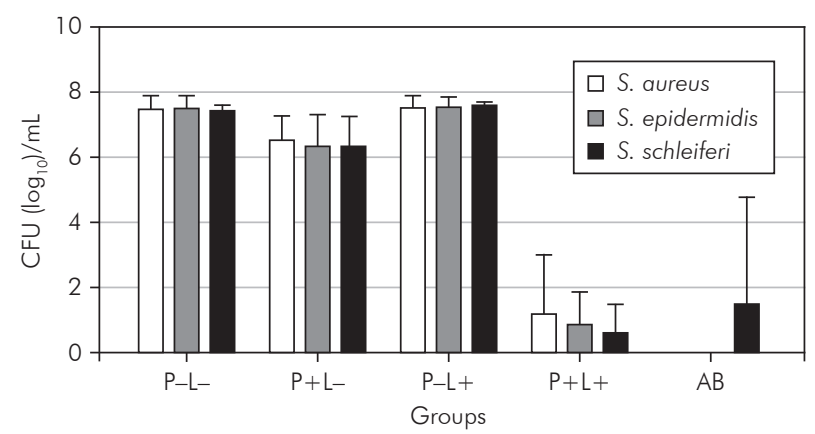

Figure 1 - Mean and standard deviation of $\log _{10}$ CFU/ $\mathrm{mL}$ obtained for S. aureus, S. epidermidis and S. schleiferi under the different experimental conditions. Experimental groups: photosensitizer and laser $(\mathrm{P}+\mathrm{L}+)$, photosensitizer alone $(P+L-)$, laser alone $(P-L+)$, saline $(P-L-)$, and antibiotic treatment $(A B)$. mental condition. A significant reduction in bacterial counts was observed for the groups submitted to PDT $(\mathrm{P}+\mathrm{L}+)$ when compared to the other groups $(\mathrm{P}-\mathrm{L}-, \mathrm{P}-\mathrm{L}+$ and $\mathrm{P}+\mathrm{L}-)$. Ciprofloxacin treatment resulted in a reduction of $100 \%$ for all the groups except for $S$. schleiferi, which presented a reduction of $5.97 \log _{10} \mathrm{CFU} / \mathrm{mL}$.

A small reduction in bacterial counts was observed for the $\mathrm{P}+\mathrm{L}-$ groups in comparison to the $\mathrm{P}-\mathrm{L}-$ groups for all species. However, the difference was only significant for two species: $S$. epidermidis and $S$. haemolyticus. The number of bacterial cells was higher in the $\mathrm{P}-\mathrm{L}+$ groups compared to the $\mathrm{P}-\mathrm{L}$ - groups, but the difference was not significant.

Table 1 shows the $\log _{10} \mathrm{CFU} / \mathrm{mL}$ reduction observed for the $\mathrm{P}+\mathrm{L}+$ groups compared to the $\mathrm{P}-\mathrm{L}-$ groups. Among the strains tested, $S$. lentus was the species most resistant to PDT, followed by $S$. aure-

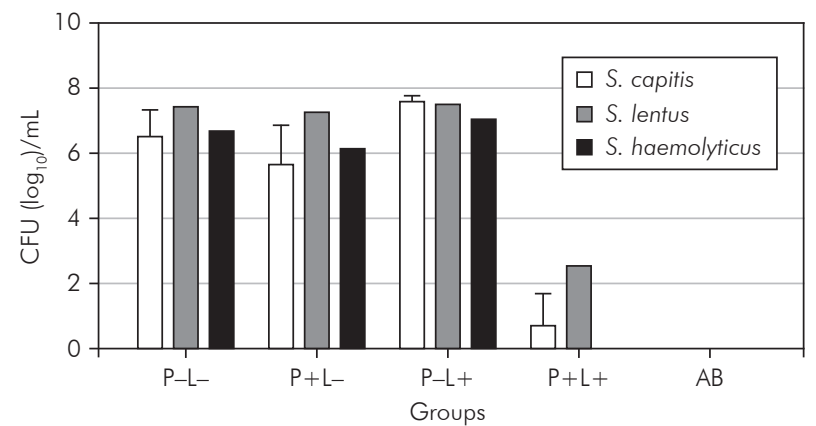

Figure 2 - Mean and standard deviation of $\log _{10} \mathrm{CFU} / \mathrm{mL}$ obtained for S. capitis, S. lentus and S. haemolyticus under the different experimental conditions. Experimental groups: photosensitizer and laser $(\mathrm{P}+\mathrm{L}+)$, photosensitizer alone $(P+L-)$, laser alone $(P-L+)$, saline $(P-L-)$, and antibiotic treatment $(A B)$.
Table 1 - Mean $\log _{10}$ CFU/mL of Staphylococcus spp. under the different experimental conditions and $\log _{10}$ reduction in the number of cells for the groups submitted to photodynamic therapy compared to the control groups. $\mathrm{P}+\mathrm{L}+$ : photosensitizer and laser; $\mathrm{P}+\mathrm{L}-$ : photosensitizer alone; $\mathrm{P}-\mathrm{L}+$ : laser alone; $\mathrm{P}-\mathrm{L}-$ : saline (control group).

\begin{tabular}{|c|c|c|c|c|c|}
\hline \multirow{2}{*}{ Strains } & \multicolumn{5}{|c|}{ CFU $\left(\log _{10}\right) / \mathrm{mL}$} \\
\hline & $\mathrm{P}-\mathrm{L}-$ & $\mathrm{P}-\mathrm{L}+$ & $\mathrm{P}+\mathrm{L}-$ & $\mathrm{P}+\mathrm{L}+$ & Reduction in $\log$ of $\mathrm{P}+\mathrm{L}+$ \\
\hline S. aureus $(n=5)$ & $7.46^{A}$ & $7,51^{\mathrm{A}}$ & $6.51^{\mathrm{A}}$ & $1.19^{B}$ & 6.27 \\
\hline S.epidermidis $(n=6)$ & $7.49^{\mathrm{A}}$ & $7.53^{\mathrm{A}}$ & $6.33^{\mathrm{B}}$ & $0.86^{c}$ & 6.63 \\
\hline S. schleiferi $(n=5)$ & $7.44^{\mathrm{A}}$ & $7.59^{A}$ & $6.32^{A}$ & $0.61^{c}$ & 6.83 \\
\hline S. capitis $(n=2)$ & $7.10^{\mathrm{A}}$ & $7.60^{A}$ & $5.68^{A}$ & $0.71^{\mathrm{B}}$ & 6.39 \\
\hline S. haemolyticus ( $n=1)$ & $6.71^{\mathrm{A}}$ & $7.06^{A}$ & $6.15^{\mathrm{B}}$ & $0.00^{c}$ & 6.71 \\
\hline S. lentus $(n=1)$ & $7.44^{\mathrm{A}}$ & $7.53^{\mathrm{A}}$ & $7.26^{\mathrm{A}}$ & $2.55^{\mathrm{B}}$ & 4.89 \\
\hline \multicolumn{5}{|c|}{ Mean } & 6.29 \\
\hline
\end{tabular}

A, B and C: statistically significant difference (Tukey's test, $p \leq 0.05$ ). 
us, S. capitis, S. epidermidis, S. haemolyticus, and S. schleiferi.

\section{Discussion}

In the present study, PDT resulted in a mean reduction of $6.29 \log _{10} \mathrm{CFU} / \mathrm{mL}$ in comparison to the control group ( $\mathrm{P}-\mathrm{L}-)$, a reduction greater than reported in some other studies. ${ }^{12-14}$ Grinholc et al. ${ }^{12}$, treating MRSA and methicillin-sensitive $S$. aureus (MSSA) strains with $25 \mu \mathrm{M}$ protoporphyrin irradiated with $624 \mathrm{~nm}$ light, observed a reduction of 0 to $3 \log$ for MRSA and of 0.2 to $3 \log$ for MSSA, demonstrating a similar sensitivity to PDT for $\beta$-lactamresistant and -sensitive strains. Wainwright et al. ${ }^{13}$ studied the effect of phenothiazine dyes irradiated with visible light (350-800 nm) on an S. aureus reference strain and on MRSA. The reduction in bacterial counts achieved with PDT was $4 \log _{10}$ when $5 \mu \mathrm{M} \mathrm{MB}$ was used for the reference strain and 10 to $50 \mu \mathrm{M} \mathrm{MB}$ for MRSA. In another study, Tubby et al. ${ }^{14}$ were able to kill approximately $6 \log$ MRSA cells with PDT, using $20 \mu \mathrm{M} \mathrm{MB}$ and a laser light dose of $9.65 \mathrm{~J} / \mathrm{cm}^{2}$. In addition, PDT reduced the activity of V8 protease and $\alpha$-hemolysin by $100 \%$ and the activity of sphingomyelinase by $92 \%$. The authors suggested that the reactive oxygen species formed during PDT interact with, and inactivate, bacterial virulence factors, providing an additional mechanism for the antibacterial action of this therapy.

The formation of a biofilm, observed in Staphylococcus strains, increases their resistance to antibiotics and protects the cells against the action of the immune system..$^{15}$ Sharma et al. ${ }^{16}$ studied the effects of PDT on biofilm formation in MRSA and $S$. epidermidis and observed that toluidine blue, combined with a diode laser, showed low antibacterial activity. In addition, $S$. aureus was more resistant to PDT than S. epidermidis.

\section{References}

1. Loberto JCS, Martins CAP, Santos SSF, Cortelli JR, Jorge AOC. Staphylococcus spp. in the oral cavity and periodontal pockets of chronic periodontitis patients. Braz J Microbiol. 2004 Jun;35(1-2):64-8.
Zolfaghari et al. ${ }^{17}$ evaluated the in vivo effect of PDT in mice with excisional and superficial skin wounds inoculated with a suspension of MRSA. The wounds were treated with $0.3 \mu \mathrm{M} \mathrm{MB}$ and irradiated with $360 \mathrm{~J} / \mathrm{cm}^{2}$ of diode laser light for $30 \mathrm{~min}$. Treatment resulted in a reduction of $1.4 \log _{10} \mathrm{CFU} /$ $\mathrm{mL}$ in excision wounds and of $1.15 \log _{10} \mathrm{CFU} / \mathrm{mL}$ in superficial wounds. The authors emphasized the importance of these results because they represent the first report of the in vivo killing of MRSA and raise the possibility of attempting to reproduce this treatment in humans.

In the present study, administration of the dye alone exerted a low antimicrobial effect, with a significant difference being observed only for S. epidermidis and $S$. haemolyticus. A dye concentration of $3 \mathrm{mM}$ was used, which exhibits low toxicity. ${ }^{18-20}$ Gois et al. ${ }^{21}$ also reported a reduction in the number of $S$. aureus cells of $0.97,0.97$ and $1.05 \log _{10}$ when irradiated with red LED $\left(20 \mathrm{~J} / \mathrm{cm}^{2}\right)$ and diode laser light $\left(20\right.$ and $\left.40 \mathrm{~J} / \mathrm{cm}^{2}\right)$, respectively, in the absence of a photosensitizer.

Ciprofloxacin used in the present study is a broad spectrum antibiotic with potent activity against bacteria of the genus Staphylococcus. ${ }^{22}$ This antibiotic killed all of the strains studied, except for one $S$. schleiferi isolate. This latter finding may be due to previous exposure of this microorganism to the antibiotic or to the development of primary resistance. However, among the Staphylococcus species submitted to PDT, S. schleiferi was the most sensitive, with a mean reduction of $6.83 \log _{10} \mathrm{CFU} / \mathrm{mL}$, suggesting that PDT might be used as an alternative for the treatment of antibiotic-resistant strains.

\section{Conclusion}

PDT was effective in reducing the number of viable cells of all clinical Staphylococcus isolates studied.

\footnotetext{
2. Martins CAP, Koga-Ito CY, Jorge AOC. Presence of Staphylococcus spp. and Candida spp. in the human oral cavity. Braz J Microbiol. 2002 Sep;33(3):236-40.

3. Casey AL, Lambert PA, Elliott TSJ. Staphylococci. Int J Antimicrob Agents. 2007 May;29 Suppl 3:S23-S32.
} 
4. Sakoulas G, Moellering Jr RC. Increasing antibiotic resistance among Methicillin-Resistant Staphylococcus aureus strains. Clin Infect Dis. 2008 Jun;46 Suppl 5:S360-7.

5. Tomás I, Pereira F, Llucián R, Poveda R, Diz P, Bagán JV. Prevalence of bacteraemia following third molar sugery. Oral Dis. 2008 Jan;14(1):89-94.

6. Zuanazzi D, Souto R, Mattos MBA, Zuanazzi MR, Tura BR, Sansone C, et al. Prevalence of potential bacterial respiratory pathogens in the oral cavity of hospitalised individuals. Arch Oral Biol. 2010 Jan;55(1):21-8.

7. Smith AJ, Robertson D, Tang MK, Jackson MS, MacKenzie D, Bagg J. Staphylococcus aureus in the oral cavity: a three-year retrospective analysis of clinical laboratory data. Br Dent J. 2003 Dec;195(12):701-3.

8. Tada A, Senpuku H, Motozawa Y, Yoshihara A, Hanada N, Tanzawa H. Association between commensal bacteria and opportunistic pathogens in the dental plaque of elderly individuals. Clin Microbiol Infect. 2006 Aug;12(8):776-81.

9. Minto ECM, Barelli C, Martinez R, Darini ALC. Identification and medical importance of coagulase-negative staphylococci species. Sao Paulo Med J. 1999 Jul;117(4):175-8.

10. Wainwright M. Photodynamic antimicrobial chemotherapy (PACT). J Antimicrob Chemother. 1998 Jul;42(1):13-28.

11. Hamblin MR, Hasan T. Photodynamic therapy: a new antimicrobial approach to infectious disease? Photochem Photobiol Sci. 2004 May;3(5):436-50.

12. Grinholc M, Szramka B, Kurlenda J, Graczyk A, Bielawski KP. Bactericidal effect of photodynamic inactivation against methicillin-resistant and methicillin-susceptible Staphylococcus aureus is strain-dependent. J Photochem Photobiol B. 2008 Jan 30;90(1):57-63.

13. Wainwright M, Phoenix DA, Laycock SL, Wareing DRA, Wright PA. Photobactericidal activity of phenothiazinium dyes against methicillin-resistant strains of Staphylococcus aureus. FEMS Microbiol Lett. 1998 Mar 15;160(2):177-81.

14. Tubby S, Wilson M, Nair SP. Inactivation of staphylococcal virulence factiors usiing a light-activated antimicrobial agent. BMC Microbiol. 2009 Oct 5;9:211.

15. Lynch AS, Robertson GT. Bacterial and fungal biofilm infections. Annu Rev Med. 2008 Oct 15;59:415-28.

16. Sharma M, Visai L, Bragheri F, Cristiani I, Gupta PK, Speziale P. Toluidine blue-mediated photodynamic effects on staphylococcal biofilms. Antimicrob Agents Chemother. 2008 Jan;52(1):299-305.

17. Zolfaghari PS, Packer S, Singer M, Nair SP, Bennett J, Street $\mathrm{C}$, et al. In vivo killing of Staphylococcus aureus using a light-activated antimicrobial agent. BMC Microbiol. 2009 Feb 4;9:27.

18. Zeina B, Greenman J, Purcell WM, Das B. Killing of cutaneous microbial species by photodynamic therapy. Br J Dermatol. 2001 Feb;144(2):274-8.

19. Banks JG, Board RG, Carter J, Dodge AD. The cytotoxic and photodynamic inactivation of micro-organisms by rose Bengal. J Appl Bacteriol. 1985 Apr;58(4):391-400.

20. Usacheva MN, Teichert MC, Biel MA. Comparison of the methylene blue and toluidine blue photobactericidal efficacy against Gram-positive and Gram-negative microorganisms. Lasers Surg Med. 2001;29(2):165-173.

21. Gois MM, Kurachi C, Santana EJB, Mima EGO, Spolidório DMP, Pelino JEP, et al. Susceptibility of Staphylococcus aureus to porphyrin-mediated photodynamic antimicrobial chemotherapy: an in vitro study. Lasers Med Sci. 2010 May;25(3):391-5.

22. Pace MA, Watanabe E, Facetto MP, Andrade D. Staphylococcus spp. In the saliva of patients with orotracheal intubation. Rev Panam Infectol. 2008 Apr-Jun;10(2):8-12. 